(Some quotations are allusions; most have other functions.) In plagiarism, one repeats another's words without acknowledgment, hoping that the reader will attribute them to oneself. In indirect allusion, one repeats or adapts another's words without acknowledgment but hopes the reader will spot the spur and understand the allusive purpose of the repetition, rather than condemning it as robbery. Again, indirection has its risks.

Another metaphor for allusion is the coil of a car's ignition system, which strengthens an already existing current to the point where it can jump the gap in the spark plug.

Machacek offers some interpretations of Prufrock's allusion to Hamlet (527): the allusion may also suggest that Prufrock was not meant to be at all, was not meant to exist. Or, closer to the terms of the allusion, was meant not to be.

The double signifier: a reprise can be seen as signifying two kinds of signifieds. Its words mean what they normally mean, but taken together they also signify the spur. This effect is somewhat analogous to the way my speech, besides its conceptual content, signifies that I probably wasn't brought up in Texas, Ottawa, or Liverpool. This aspect of allusion calls for more investigation.

The multiple allusion: a single reprise can often allude to two or more spurs, in one or more earlier authors. Paradise Lost offers especially rich possibilities here. It is relentlessly cross-referential or autoallusive, and its autoallusions are often parodic: e.g., Satan, Sin, and Death are an infernal trinity that parodies the heavenly trinity of Father, Son, and Holy Spirit. In The Dunciad, Pope often alludes to two or three such spurs at once-i.e., both to a basic text and to Milton's parody of it (and sometimes simultaneously to the Bible or Blackmore's Creation or Dryden's Mac Flecknoe), thus exponentially enriching his own text. Wordsworth sometimes uses Paradise Lost this way in The Prelude. The earliest explicit description of multiple allusion that I know of is Michael Wilding's "Allusion and Innuendo in Mac Flecknoe" (Essays in Criticism 19 [1969]: 355-70).
One of Machacek's examples (526) is really a double allusion. Milton's "In the beginning" (Paradise Lost 1.9) alludes not only to Genesis 1.1 but also to the opening of Saint John's Gospel, "In the beginning was the Word," which itself alludes to Genesis 1.1. Bringing John's spur into action emphasizes the role of God's word in creating the world, in inspiring the words of Moses that repeat the word of creation, and, Milton hopes, in making his own words worthy of their subject. Theologically, it implies the unity of the Old and New Testaments.

Envoi: Machacek's essay is well designed to stimulate the sustained theoretical study that allusion deserves but has not yet received. Remember, the abbreviation of allusion is all.

William Kinsley

Université de Montréal (retired)

\section{Genre and the Memoir}

\section{To THE Editor:}

Nancy Miller's essay “The Entangled Self: Genre Bondage in the Age of Memoir" (122 [2007]: 537-48) offers wide-ranging and provocative musings on the complexity of memoir writing-an ever more elusive, ambivalent, and nowadays almost indefinable genre. I hope it is not out of order to add to the many variants of "truth-telling" and "truth-reflecting" that Miller explores one other approach I consider valid, even though it may be somewhat unorthodox, perhaps even simplistic.

My recent book, Ten Dollars in My Pocket: The American Education of a Holocaust Survivor, is labeled a memoir - not quite accurately so, for it presents separately aspects that in many memoirs are interwoven and thereby make it difficult for the reader to differentiate among objective, reflected, or manipulated facts, emotional or critical coloration, creative expansion or compression, distortion, and so forth. The book juxtaposes the following elements: diary entries, published articles, letters, and documents, all written during the period in question and presented verbatim or, if needed, 
in close translation; commentary linking, explaining, or amplifying the above texts, whenever necessary or desirable; reflections on and assessments of the documents from the perspective of the mature narrator; finally, a frame outlining the purpose, procedure, and goal of the exploration to be undertaken and inviting readers to make their own assessment of the narrator, then and now.

This approach, I believe, enables readers to extricate from the memoir the degree of information and truthfulness they expect or are interested in, be it factual, psychological, emotional, or aesthetic, without having to question or try to trace the presenter's perspective and motive. And just as it is up to the viewer of a painting to read meaning into or out of it and up to listeners to establish a relation with the music they hear, so the reader of such a memoir need not worry about its historical accuracy but can accept it as a glimpse into the life of another being, hopefully presented with such aesthetic components as form, structure, and style but without hiding manipulation or invention.

Elizabeth Welt Trahan Amherst College (retired)

\section{Leadership for a Diverse Profession}

\section{To THE EDITOR:}

Marjorie Perloff offers a most interesting and thoughtful survey of the state of the profession in her 2006 Presidential Address (122 [2007]: 652-62), but I must point out one blind spot, unfortunately common for people with prestigious appointments in English and foreign language departments. She writes, "Given these aporias of literary study, administrators are beginning to argue, perhaps English departments should concentrate on the study of composition and rhetoric, disciplines that really do teach students things they need to know, and the foreign literature departments should focus on language learning, so important in business, professional life, and especially government service" (656). She implies this is a future possibility we should watch out for rather than a present reality. This passage suggests the former president of the MLA was, unfortunately, oblivious to the actual state of the profession. Overwhelmingly, English departments are composition departments, and foreign language departments are "language learning" departments. A glance at the course offerings of almost any college or university shows that literature courses make up only a fraction of the departments' total teaching load. The higher one's professional status, of course, the less likely one is to teach the nonliterature courses, leaving that work to graduate students, part-timers, temps, composition and language education specialists, and a significant percentage of the faculty at most nonelite schools (for whom such courses constitute a chunk of their teaching load) - that is, to the bulk of the profession below the top tier.

Look, I'm not saying that the MLA should reorient itself to focus on the predominant mode of work that English and language departments actually do-the literary focus is extremely valuable, the lure that got most of us into this business in the first place. I'm asking for a leadership that can see below the summit.

What would happen if the MLA elected its presidents from an activist bottom rather than a prestigious top?

James $D$. Sullivan

Illinois Central College

\section{Reply:}

I am grateful to James D. Sullivan for raising this issue. He is right to remind us that, even now-not just in some hypothetical future-in most large state universities, "English departments are composition departments, and foreign language departments are 'language learning' departments." The truth, I suppose, is that, whatever the reality on the ground, the discourse of our discipline-indeed, of any academic discipline-draws its inferences from graduate programs at the top universities, and at these universities, as well as at liberal arts 